\title{
Theorization the Use of Podcasts as an Alternative Medium of Da'wah and its Impact on the Audience: The Case of Indonesia
}

\author{
Arina Rohmatul Hidayah
}

Department of Islamic Broadcasting and Communication, Faculty of Da'wah, Institut Agama Islam Tribakti (IAIT) Kediri, East Java 64114, Indonesia

\begin{abstract}
The purpose of this research is to provide novelty in the study of communication science, especially on the role of new media, namely podcasts as a medium of da'wah, which so far has not been widely studied. Through a phenomenological approach and conducted interviews with two uploaders da'wah content of Baha'uddin Nursalim, and two active listeners, the results obtained that podcast as an alternative medium of $d a$ 'wah is a message about society's civilization towards the need for auditory media to obtain religious content is increasing. Moreover, users and listeners are considered quite active in choosing an effective medium of $d a$ 'wah because podcasts provide several advantages during high community mobility and an adaptive and dominative effort to strengthen the existence of Nahdlatul Ulama organizations in the digital era.
\end{abstract}

Keyword: Digital age, impact on the audience, medium of da'wah, podcast

ARTICLE INFO

Article history:

Received: 3 July 2021

Accepted: 8 October 2021

Published: 8 December 2021

DOI: https://doi.org/10.47836/pjssh.29.4.29

E-mail address:

arinarohmatulh@gmail.com

\section{INTRODUCTION}

Current technological developments require people to innovate in various aspects, one of which is in the field of $d a$ 'wah. Historically, da'wah in Indonesia has been carried out through various approaches, be it social, cultural, political, and economical. So that in its application, the da'wah movement will take place dynamically according to the social context of society. It is included in the digital era like now. Before the existence 
of new media, da'wah was carried out through personal approaches, such as trade, arts and cultural media, and even political channels. When mass media, such as radio, newspapers, and television, emerged, da'wah's method differed. Especially with the existence of new media, where the reach of its spread is much more massive and global. Of the many new media presence in the community, one alternative that can be used as a medium for $d a$ 'wah is podcasts.

According to Zaenudin (2019), podcasts were born with the birth of the iPod, an audio player made by Apple that Steve Jobs introduced in 2001. Podcast, which stands for "iPod broadcasting," or broadcast using IPod, is a non-linear radio broadcast. Similar to YouTube, it provides content for listeners on an on-demand basis when the listener wants it. Indirectly, podcasts here have some similarities with radio. While for the difference between the two are that the content on podcasts can be downloaded, and users are free to choose the content. For radio, listeners can only choose a radio frequency, and if they want to listen to their favorite program or content, they must wait until the specified time-cannot be done at any time. It means podcasts are not present based on stations or frequency like regular radio but use various types of content. There are podcasts about socio-culture, politics, entertainment, sports, mystical, fictional dramas, and the discussion of Islamic values is no exception. After conducting a search using Spotify (a music application that provides a podcast feature in it), the researcher saw that there were several contents from the religious teacher, such as
Hanan Attaki, Ustadz Abdul Somad, Adi Hidayat, Ulil Abshar Abdalla, or Gus Ulil to Baha'uddin Nursalim or Gus Baha.

The use of podcasts is considered to provide great opportunities for the $d a$ 'wah movement in Indonesia. However, not as many as America and several countries in Europe, the popularity of podcasts in Indonesia is predicted to increase. Zaenudin (2019) explains that referring to research conducted by Edison Research; there are 39 million podcast listeners in the United States. According to data reported by Statista, 24 percent of adults in the United States consume podcast broadcasts. Meanwhile, in Indonesia, according to the report written by DailySocial entitled "Podcast User Research in Indonesia 2018," 68 percent of their total respondents stated that they were familiar with podcasts. More than 80 percent of respondents admitted to listening to podcasts. It is reinforced by the explanation from gatra.com, the media industry player and founder of the box2box football podcast, Pangeran Siahaan, predicting that 2020 will be the golden year of Indonesian audio podcast broadcasts. According to him, the trend of media popularity will always repeat itself. He said, next year, there will be a talkative phase, where Indonesians will later make podcasts a lifestyle trend, and many will use this audio platform (Novrizaldi, 2019). It can be seen from the many podcasts of domestic children on various platforms, such as Spotify, Apple Cast, Google Podcasts, Pocketcast, Anchor, Inspigo, and so on (Zellatifany, 2020). 
It is interesting, from this explanation, to examine how the current popularity of podcasts is a positive aspect in supporting the development of $d a$ 'wah in Indonesia. Why $d a$ 'wah and no other aspects? Because according to some existing research, podcasts are considered effective as a medium of learning, both at school and in college (e.g., Alfian et al., 2019; Harahap, 2020). Moreover, this benefit can be used or explored in other fields, including $d a$ 'wah, because based on the majority of previous research, the use of $d a$ 'wah media is limited to social media (e.g., Briandana et al., 2020; Wibowo, 2019) and conventional media (e.g., Kaddas \& Ishak, 2018; Siagian et al., 2016). Thus, a new alternative media is needed to disseminate $d a$ ' wah content more massive and reach all people. Moreover, in that context, podcasts can be the main choice because of the increasing usage trend in Indonesia.

Based on this background, the researcher intends to raise the da'wah content of Baha'uddin Nursalim as the object of research. Gus Baha is one of the religious teachers who now has many followers on social media. As reported by Redaksi (2021), in one video on YouTube, the audience of Gus Baha's da'wah even reached 57 thousand. Just like the statement from Rusydiyah et al. (2020), the number of viewers of Gus Baha's study on YouTube reaches four to eight million in one year. It was motivated by the fact that the religious studies presented by Gus Baha were quite in-depth. He grew up in a family that was expert in the Qur'an, especially from his father's family. Plus, his educational history has studied at the Al-Anwar Sarang Islamic Boarding School under the auspices of a great religious teacher in Indonesia, namely KH. Maimoen Zubair (Redaksi, 2021).

Although the research object here refers to da'wah of Gus Baha content, it does not mean that Gus Baha also shares it through podcasts. Instead, their active followers share the material they get, through podcasts or other social media as stated by Ulil Abhsar Abdalla or Gus Ulil, one of the religious teachers whose $d a$ 'wah content is also uploaded to the podcast, the content of his recitation, which is distributed through Spotify is a continuation of the content on Facebook (Zaenudin, 2019). Indeed, for some senior religious teachers, most of their $d a$ 'wah content is uploaded by their followers. In contrast, younger or modern religious leaders can upload their content directly through podcasts, such as Hannan Attaki.

In this study, researchers will focus on several points, namely: the motive for using podcasts by followers of Gus Baha at the Izzati Nuril Qur'an Bantul Yogyakarta Islamic Boarding School and Al-Anwar Sarang, its effectiveness in distributing $d a$ 'wah contents from communicators and listener perspectives, and data findings obtained based on some of these aspects will be analyzed using relevant theories.

The output of this research is expected to provide a comprehensive picture of how media digitization can present a new format for conveying messages. Although podcasts are not the only effective media for $d a$ ' $w a h$, 
with some benefits that other media do not have, this media can be an alternative for users. Thus, the distribution of $d a$ 'wah content can run more massively (the more media used, the public's awareness of Islamic teachings is expected to increase), deep, effective, and efficient. Not only in terms of content distribution, by examining the impact of using podcasts on listeners, this research will also provide interesting findings of the extent to which podcasts are effective as a variant of new media present in society.

\section{THEORETICAL BASIS}

\section{Da'wah Media}

According to Aziz (2017), da'wah comes from Arabic " $d a$ 'wah" in terms of language, and $d a$ 'wah has three original letters, namely dal, 'ain, and wawu. From these three original letters, several words and various meanings are formed. The meaning is calling, inviting, asking for help, begging, naming, telling to come, encouraging, causing, bringing, praying for, weeping, and lamenting. Aziz (2017) emphasizes some of the words above, which in the end can give that $d a$ 'wah is persuasive, namely inviting humans subtly. Violence, coercion, intimidation, threats, or terror so that someone implements Islamic teachings cannot be said to be da'wah. This understanding is obtained from the meaning of da'wah, which means inviting, praying, complaining, calling, asking, and inviting. Tracing the meaning of $d a$ 'wah also shows that these meanings designate a word that requires an object. It shows that there is always a $d a$ 'wah target. There are at least three components in $d a^{\prime}$ wah activities: $d a$ 'wah actors (preachers), $d a$ 'wah messages, and $d a$ 'wah targets. In line with the above statement, Qarni et al. (2019), in their Journal Verbal and Nonverbal Factors Influencing the Success of $D a$ 'wah Communication by Ustadz Abdul Somad, also emphasized the definition of $d a$ ' wah in the meaning of inviting. According to him, $d a$ 'wah literally means "issuing a call" or "making an invitation." It serves to invite people to understand Islam through dialogue. In performing this function, a Muslim with a deep understanding of Islamic teachings is needed, called a religious teacher. In the process of $d a$ 'wah, it is necessary to involve communication that encourages social interaction between preachers and their listeners. For this reason, a religious teacher should have extensive knowledge related to Islamic teachings, human social behavior, and the socio-cultural environment in which they live (Mubarok, 1999, in Qarni et al., 2019).

The essence of $d a$ 'wah from the two previous sources shows that da'wah emphasizes the existence of a process that involves three actors: the communicator, the message, and the communicant. Of course, what is called a process requires adaptation efforts. When da'wah can be interpreted as an invitation or invitation so that the public can understand the teachings of Islam, the actors in it (or in this case, the active role of preachers) must think of various effective strategies to reach audiences in accordance with existing socio-cultural 
conditions, including the $d a$ 'wa media used. Abdullah (2019) states that media is a tool or vehicle to transfer messages from source to recipient. Therefore, according to him, $d a$ 'wah can be divided into two: non-media da'wah and media da'wah. Da'wah media can be divided into two: communication using mass media and communication using individual media. Included in the mass media are the press, radio, film, television, and the internet. Meanwhile, the media, which includes individual communication media, are letters, telegrams, telephones, and so on.

Slightly different from Abdullah (2019), Aziz (2017) classifies da'wah media into three, namely spoken media, tools that can make sounds, such as radio, telephone, and others, while written media (the printed writing), media in the form of writing or print, such as magazines, newspapers, books, pamphlets, paintings, pictures as well as audio-visual media, media containing live images that can be seen and heard, such as films, videos, television and so on. In addition, according to Aziz (2017), some divide da' wah media into two points, namely traditional media (without communication technology) and modern media (with communication technology).

From several concepts about the definition of $d a$ 'wah, which emphasizes the process of delivering religious messages from communicators to communicants through certain media (Aziz, 2017; Qarni et al., 2019) and several categorizations of da'wah media proposed by Aziz (2017), the operationalization of the concepts used in this study seeks to combine the concept of spoken media, especially radio, with modern media using the latest communication technology. Podcasts represent that combination, where the characters resemble radio and are packaged using digital technology. However, it is undeniable that talking about the $d a$ 'wah process caused an effect, it is necessary to adapt to the existing conditions to produce the desired impact, and one of them is through the adjustment of the da' wah media. It does not mean that other da'wah media are abandoned. On the contrary, new media alternatives trending in society are needed to expand the distribution of $d a$ 'wah content and reach all elements of society.

\section{Podcast and Its Role as a $\mathrm{Da}$ 'wah Media}

Regarding the concept of the podcast, Abdulrahman et al. (2018) explain that the term "Podcast "was derived from two technologies, "iPod," and "Broadcast." A podcast is the same as radio, but there is a thin line between radio and Podcast. Although it resembles radio in terms of delivery, both emphasize the concept of a theater of the mind; there are still differences. If we want to listen to a program on a certain radio station, we must wait for a predetermined period, and the nature of the delivery is just a cursory hearing. When we miss just one topic, it will be difficult to repeat it. As for podcasts, we can hear any content we like without knowing the time limit. Plus, through podcasts, we can download the content and play it repeatedly according to taste. 
With the above facilities, it is only natural that podcasts have several benefits or roles in the message delivery process. Although no one has discussed the role of podcasts in da'wah's world, at least some literature shows the importance of podcasts for the education system. It was explained by Sansinadi et al. (2020) who assessed that podcast could help teachers and students to achieve learning goals. Teachers can give assignments outside of class through podcasts, as well as students, where podcasts can help them provide an in-depth understanding of the subject matter. There are many channels and languages available. In addition, the material can be downloaded via mobile phones, so students can listen to it anywhere and repeat it without an internet connection. Not only that, but Dianithi (2017) also adds the advantage of using podcasts as a learning medium, which allows for classes without face-to-face. According to him, podcasts can increase student motivation, help to teach large-scale classes, can be used to teach mixed ability students, and podcasts can pay attention to accuracy. Behind the benefits that can be felt, there are also potential downsides to using podcasts. Scutter et al. (2010) added that some academic staff expressed concern about students who no longer attend the learning process and choose to leave the academic world. It is also relevant to the emergence of the potential for student inactivity.

Referring to the benefits that have been stated above, even though they are in a different domain, it is clear that they can also be felt in the $d a$ 'wah environment. Da'wah and the education system, in general, are not much different. Da'wah also emphasizes the learning process; it is just based on religious values. By using podcasts, people can indirectly deepen the religious content of their favorite religious teacher, download, and listen to them continuously. They can also have alternative media when the religious teacher carries out the da'wah in an area far from reach. They can still follow the material through podcasts. Apart from the benefits that can be obtained, it must be acknowledged that when the facilities for obtaining content become easier, it is also possible for the community to be inactive in various recitation forums. They can tend to listen through podcasts rather than go to the trouble of coming to the show. So that indirectly, the presence of media, such as podcasts, has narrowed the reach of social interaction among the congregation. Therefore, the presentation of the benefits and potential harm caused by podcasts can be used as a basis for analyzing the data findings in the field.

\section{Theories Relevant to Data Findings}

Referring to the grand theory of Littlejohn et al. (2017), the researchers will use theories relevant to this context, namely media ecology, uses and gratifications, and political economy media as a critical study.

\section{Media Ecology Theory}

Neil Postman first coined this theory in 1970. He is interested in how communication media affect human perception, understanding, 
feelings, and values. Postman chose the term ecology because it denotes the study of the environment: their structure, content, and impact on humans (Littlejohn et al., 2017). The term eventually became a reference for Marshall MC Luhan and several other media theorists so that the concept of medium is the message emerged. The most important thing about the presence of media is not the message or content but the media itself. Euchner (2016) explains that the medium is the message, emphasizing the implications of each new technology (or media) outside the specific context of its use. This message can be summarized into four "laws of media:" any new technology, or "human extension" 1) intensifies or enhances something in the world 2) makes something else obsolete 3 ) takes on some of the attributes of the past, and 4) and at the extreme, back into the caricature itself.

In essence, media ecology theory emphasizes the role of media as an extension of the human body and even their minds and consciousness (Laskowska \& Marcynski, 2019). Therefore, McLuhan and Neil Postman themselves believe that the relationship between media and the environment lies in the function of the media, the impact of media on human life, the dependence between humans and the new media environment (Laskowska \& Marcynski, 2019).

According to Mc Luhan's concept, media is an extension of the human body. That way, the media tries to meet the needs desired by humans as an interaction between society and their environment. So, media is an environment, and this environment will adapt to the objects in it. Therefore, although the media has an important role as a message about human civilization, we cannot rule out the role of a human in shaping the desired social civilization. It is relevant to the uses and gratification theory, which also looks at the role or activity of the community in choosing the media. It is not only the media that has a full role in influencing society.

\section{Uses and Gratification}

Mehrad and Tajer (2016) explained that the uses and gratification theory is one theory that focuses on social communication. This theory adopts a functionalistic approach to communication and media and states that the most important function of the media is to meet the needs and motivations of society. Littlejohn et al. (2017) revealed five assumptions in the uses and gratification theory, the audience actively chooses the media they want to use. Second, the audience is active and goal directed. Third, various media compete for the attention of the audience. Fourth, social and contextual elements shape the activities of the audience. Finally, media effects and audience use of media are interrelated. That is, the media will only have an impact on the audience who consumes it. These five assumptions will be used by researchers to determine to what extent users are active in using podcasts as a medium of $d a^{\prime}$ wah.

\section{Political Economy of Communication}

When media ecology talks about the phenomenon of using podcasts as a message 
of changing social civilization in society and uses and gratifications analyzes user activity in choosing media, in examining the motives for using podcasts, it can be seen through a political economy theory of communication. The political economy of media is narrowly defined by Mosco (2009) as a study of the power relations that shape the production, distribution, and consumption of sources, including communication sources, and broadly leads to control studies and social survival efforts. From this theory, there are three entrances, namely commodification, spatialization, and structuration. Mosco (2009) explains that commodification is the process of changing or converting the value of goods into exchange rates. There are three types of commodification in the media industry: content commodification, audience commodification, and the commodification of media workers (in Muslikhin et al., 2021). Furthermore, according to Mosco (2009), spatialization is related to the extent to which the media can present their products to an audience within space and time constraints. Finally, structuring is described as the process by which social structures are upheld by social agents, which later become part of the structure and act to serve other parts. This structure explains the relationship of ideas between community agents, social processes, and social practices (in Muslikhin et al., 2021). The definition and three entrances of political economy theory can be used not only for the media industry with a certain organizational structure but in other words, it can be personally controlled by anyone. Likewise, the role of podcasts as a medium of $d a$ 'wah. Most $d a$ 'wah content on podcasts does not come from the media industry but can come from modern religious teachers. For senior religious teachers, $d a$ 'wa materials are usually uploaded by followers who have podcast accounts.

\section{METHOD}

This research is based on a qualitative approach with a phenomenological study. Phenomenological studies can be defined as a research approach that intends to describe the essence of a phenomenon by exploring it from the perspective of an experienced subject (Neubauer et al., 2019). This research departs from a trend or phenomenon in Indonesia regarding the increasing use of podcasts. So, from this phenomenon, through a phenomenological approach, researchers will conduct in-depth interviews with several respondents who use podcasts as a medium of $d a$ 'wah to find out and describe their experiences related to it. To determine the sample, the researcher used a purposive sampling technique in which he had determined the direction of the research. The researcher would select informants or respondents who had indeed uploaded Gus Baha's da'wah through podcasts. Many accounts upload da'wah material of Gus Baha through podcasts, but their identity cannot be known. Only two accounts have identities, names, and cellphone numbers, namely Ngaji Gus Baha and Santri Gayeng. For Ngaji Gus Baha account was initiated by Nur Muhammad Dwi Putranto, active followers at the Izzati Nuril Qur'an Bantul 
Yogyakarta and for SantriGayeng admin is Rumail Abbas from Al-Anwar Islamic Boarding School Sarang. So that, from these two informants, the researchers will dig deeper about the motives for using podcasts as a medium of $d a$ ' wah. In addition, purposive sampling is also aimed at active listeners of Gus Baha's podcast. Similar to the identity of previous communicators, in this case, due to the lack of interactive features in podcasts, researchers are also less than optimal in finding data for active listeners. So far, through the search results, there are two listeners whose identities are known clearly, namely Sudiono and Hilda Royn. Although it is a bit difficult to find the listener's identity, the researcher considers that to find out the effectiveness of using podcasts as a medium of $d a$ 'wah, it is also necessary to study from the side of the communicant. Because, after all, in a communication process, the final goal to be achieved is the effect of the message sent by the communicator to the communicant.

Meanwhile, the data analysis technique includes three processes: data reduction, data display, and conclusion and verification (Miles \& Huberman, 1992, in Rijali, 2018). First, raw data from the interview process will be selected or sorted according to the focus of the study, then presented in the form of data descriptions, and conclusions can be drawn from this description. The researcher used the data triangulation technique for the verification stage by conducting interviews with various parties, from uploading Gus Baha's da'wah through podcasts to direct listeners. In addition, this research is also supported by secondary data in the form of literature studies on relevant theories and previous research.

\section{DATA FINDING AND DISCUSSION}

Based on the research focus previously mentioned, the researcher conducted in-depth interviews with users or communicators who uploaded Gus Baha's da'wah through a podcast, namely Nur Muhammad Dwi Putranto as the owner of the Ngaji Gus Baha account and Rumail Abbas as the admin of Santri Gayeng account. While for the listeners or communicants who consume the content, the researcher will conduct in-depth interviews with Hilda Royn and Sudiono. For the classification of questions, the researcher will ask Nur Muhammad Dwi Putranto and Rumail Abbas about their motivations and the advantages and disadvantages of podcasts as a medium of da'wah. As for Hilda Royn and Sudiono, the researcher asked about the impact and effectiveness of using podcasts as $d a$ 'wah media of Gus Baha. For more details, Table 1 and 2 are a summary of the results of interviews with users and active listeners.

From the answers of each respondent above, it can be analyzed through several relevant theories. The motivation for using podcasts as a medium of da'wah can be related to a critical study from Vincent Mosco. Because from the answers obtained, there is an emphasis on efforts to strengthen the existence and expansion of the audience segment in accordance with the broad meaning of the political economy of communication as control studies and 
Table 1

Summary of interview results with podcast users as Da'wah media of Gus Baha

\begin{tabular}{|c|c|c|}
\hline Name & Focus of Research & Result \\
\hline $\begin{array}{l}\text { Nur Muhammad } \\
\text { Dwi Putranto }\end{array}$ & \multirow[t]{2}{*}{$\begin{array}{l}\text { Motivation for Using } \\
\text { Podcasts as a Media } \\
\text { of } D a \text { 'wah }\end{array}$} & $\begin{array}{l}\text { Because there is a trend in society, } \\
\text { especially in the field of } d a \text { 'wah, many } \\
\text { religious figures have started to deliver their } \\
\text { content through podcasts. So, to strengthen } \\
\text { the existence of religious figures from the } \\
\text { Islamic organization Nahdlatul Ulama } \\
\text { (considering the large enough mass base in } \\
\text { Indonesia), it is also important to upload } \\
\text { Gus Baha's content through podcasts. }\end{array}$ \\
\hline Rumail Abbas & & $\begin{array}{l}\text { To expand the audience segmentation by } \\
\text { saving quota and battery }\end{array}$ \\
\hline $\begin{array}{l}\text { Nur Muhammad } \\
\text { Dwi Putranto }\end{array}$ & \multirow{2}{*}{$\begin{array}{l}\text { Advantages and } \\
\text { Disadvantages of } \\
\text { Podcasts as a } D a \text { 'wah } \\
\text { Media }\end{array}$} & $\begin{array}{l}\text { The advantages are saving quotas and } \\
\text { statistical analysis. So, you can know the } \\
\text { number of listeners and their categorization } \\
\text { The disadvantage is that podcasts are only } \\
\text { audio-based media, which sometimes, } \\
\text { Gus Baha's content cannot be understood } \\
\text { through this media, such as language } \\
\text { problems. }\end{array}$ \\
\hline Rumail Abbas & & $\begin{array}{l}\text { The advantage is also that it recognizes that } \\
\text { podcasts can save more on quota and battery } \\
\text { The disadvantage is more directed at the } \\
\text { lack of interactive features to find out what } \\
\text { listeners want for Gus Baha's material } \\
\text { uploaded through podcasts. }\end{array}$ \\
\hline
\end{tabular}

Table 2

Summary of interview results with listeners

\begin{tabular}{lll}
\hline Name & Focus of Research & Result \\
\hline Hilda Royn & $\begin{array}{l}\text { The Impact of Using } \\
\text { Podcasts as Da'wah } \\
\text { Media of Gus Baha }\end{array}$ & $\begin{array}{l}\text { The perceived impact is more on the ease } \\
\text { of understanding the content because it } \\
\text { can be heard anytime and anywhere. In } \\
\text { addition, because she likes audio media } \\
\end{array}$ \\
& $\begin{array}{l}\text { more than audiovisual media when Gus } \\
\text { Baha is present on the podcast, Hilda is } \\
\text { more able to follow him than when he is } \\
\end{array}$ \\
& on YouTube \\
&
\end{tabular}


Table 2 (Continue)

\begin{tabular}{|c|c|c|}
\hline Name & Focus of Research & Result \\
\hline Sudiono & $\begin{array}{l}\text { The Impact of Using } \\
\text { Podcasts as Da'wah } \\
\text { Media of Gus Baha }\end{array}$ & $\begin{array}{l}\text { Like Hilda, the impact that can be felt is } \\
\text { when on the go or with high mobility the } \\
\text { presence of podcasts makes it possible to } \\
\text { listen to } d a \text { 'wah of Gus Baha with battery } \\
\text { and quota savings compared to listening } \\
\text { through YouTube or listening to other } \\
\text { media. }\end{array}$ \\
\hline Hilda Royn & & $\begin{array}{l}\text { For a type like Hilda, who prefers audio } \\
\text { content to audiovisual content, Gus Baha's } \\
\text { presence is considered quite effective. } \\
\text { Because even though it is on YouTube, } \\
\text { Hilda still does not want to follow. After } \\
\text { using this kind of audio media, she is } \\
\text { interested and continues to follow the } \\
\text { content }\end{array}$ \\
\hline Sudiono & $\begin{array}{l}\text { The Effectiveness of } \\
\text { Using Podcasts as } \\
\text { Da'wah Media of Gus } \\
\text { Baha }\end{array}$ & $\begin{array}{l}\text { Unlike Hilda, Sudiono is more concerned } \\
\text { with the content delivered and under what } \\
\text { conditions. When the content delivered } \\
\text { allows it to be channeled through audio } \\
\text { media, podcasts can be quite effective. } \\
\text { Especially in any condition. As for material } \\
\text { that is not possible through audio, such } \\
\text { as prayer movements, how to perform } \\
\text { ablution, and others, audio-visual media } \\
\text { will be more effective. However, both agree } \\
\text { that the presence of podcasts can broaden } \\
\text { the audience segmentation. }\end{array}$ \\
\hline
\end{tabular}

social survival efforts (Mosco, 2009). During many religious figures from various sects, especially those who are modern and understand technological developments, who deliver their da'wah through podcasts, the effort to do the same with da'wah material of Gus Baha can be said as an effort to control and social survival. According to Mosco (2009), the control effort can be seen through the power relations that affect the production, distribution, and consumption processes. However, unlike media institutions, power relations here can also be controlled or dominated by individuals with all their interests, including maintaining their existence in the social environment. Individuals can determine the content that is created, how the content is distributed or through the media to be consumed and get the desired effect from society. Thus, through three entrances, namely commodification, spatialization, and structuration, the use of podcasts as a da'wah media of Gus Baha can be said as an 
effort to control his followers by means of spatialization. According to Mosco (2009), spatialization is related to the extent to which the media can present their products to an audience within space and time constraints (in Muslikhin et al., 2021). There are two types of spatialization, namely vertical and horizontal. Vertical spatialization occurs when the media industry expands its reach by expanding its business to other media platforms. Meanwhile, horizontal spatialization occurs when a media company expands its business to businesses other than media. Moreover, seeing podcasts as an alternative to $d a$ 'wah media of Gus Baha will be relevant to vertical spatialization, where Gus Baha's congregation uploads da'wah material via YouTube, Instagram, or Twitter and with podcasts as an effort to achieve economic and political aspects as previously explained.

In terms of advantages, disadvantages, as well as the impact and effectiveness felt by listeners, are related to each other. It is relevant to the concept of uses and gratification theory. The uses and gratification theory proposed by Elihu Kats in 1959 made five assumptions. First, the audience actively chooses from various media. Second, the audience is active and goal-directed. Third, the various available media compete to attract the attention of the audience. Fourth, social and contextual elements shape audience activity. Finally, media effects and audience use of media are interrelated (Littlejohn et al., 2017). From this explanation, the five assumptions in question can be fulfilled based on the data findings. First, the audience actively chooses from various media. Most informants, both uploaders and listeners, agree that among the various media of $d a^{\prime}$ wah, they choose podcasts because there are needs that must be met, namely saving data and battery, the importance of listening to da'wah content in any condition, which in this case, cannot be fulfilled by audiovisual media. Second, the audience is active and goal-directed. Just like in the first point, they chose podcasts as a medium of da'wah because they had a purpose. So, it can be said that listeners are actively looking for which media suits their wants and needs. Therefore, this theory clearly emphasizes the gratification aspects that users get when they use the media. However, when the media cannot provide the desired needs, users will use other media that can meet that need. As the statement from listeners, for $d a$ 'wah material that does not require movement, podcasts can be quite effective in conveying messages. However, when it comes to prayer movements, ablution, and others, it is still effective using audiovisual media. Littlejohn et al. (2017) assume, "when we look at sitcoms, we are sure that from the sitcom. We will feel entertained because indeed our need right now is entertainment. When we are not in need of entertainment, we need the latest information, for example, we are less likely to watch these shows."

Third, the various available media compete to attract the attention of the audience. In its application, uploaders of material via podcasts also compete to broadcast Gus Baha's da'wah to attract the 
attention of the public so that they are not inferior to other scholars. Fourth, social and contextual elements shape audience activity. Several informants explained that they used podcasts because they were carried away by the growing trend in society. Like Nur Muhammad Dwi Putranto's explanation, he started using podcasts because of trends abroad. Finally, media effects and the use of media by audiences are intertwined with the intention that the media only affects certain audiences who choose the media. Therefore, when informants choose podcasts to save data and battery, so they listen more often to Gus Baha's da'wah in any condition and situation as well as auditory type informants, the podcast will also have a profound impact on these kinds of people. It is different from people who like audiovisual content, for example. As with any $d a$ 'wah packaging on the podcast, it will tend not to be interesting.

Seeing the explanation above, the motivation of users to use podcasts as a medium of $d a$ 'wah is an important point in knowing the benefits of new media and as an illustration that the more media used for preaching, the wider community that can be reached. Another point that is no less important from the discussion and being used as material for further research is the need to see the role of the media itself-how new media with all the existing facilities can impact user activeness in following $d a$ 'wah content. This point is also one of the criticisms of the uses and gratification theory, which only focuses on an active audience, regardless of the media side, or the new media users will be more active and have many choices. Steiner and $\mathrm{Xu}$ (2018) also confirmed this. Their research on Binge-Watching Motivates Change: Uses and Gratifications of Streaming Video Viewers Challenge Traditional TV Research also criticized the uses and gratifications theory by stating that media technology can affect the gratification received by the audience. It is consistent with the criticism of the uses and gratifications theory, which only emphasizes the activeness of audiences using the media. Such as through their data findings, which show that the navigation and episode control owned by current technology affects binge-watching or bingewatch activity.

Responding to the criticism above, when Steiner and Xu (2018) commented on the uses and gratification theory, which looks more at the activeness of the audience than the role of the media itself, this is answered through media ecology theory. This theory assumes that the development of technology impacts the development of the history of human civilization. So that Mc Luhan said the medium is the message; it is not the message in the media that is important but the media itself, which is the message. As in ancient times, when people began to recognize reading and writing, inscriptions emerged as a medium of communication as well as forming a message that civilization at that time was progressing. Likewise, so on. When the industrial revolution occurred in 1750-1850, it became an important moment to change all aspects of human life, starting from social, cultural, economic, and political. From this change, many modern 
technologies, such as typewriters, radio, and all kinds, were created because the demands for communication are increasing. As explained by Tufan (2020), the end of the 19 th century, which coincided with the first years of the invention of radio broadcasting technology, became a period that opened limitless possibilities for broadcasting to a wide audience. With all its facilities, the radio is enthusiastically welcomed by the community and broadcasts many programs ranging from art education, entertainment, literature, sports, and others. Over time, with the development of broadcasting technology, podcasts emerged, which began to change radio in the early 2000s. However, instead of choosing the term to replace the old radio role, Tufan (2020) calls this changes the podcast role as an extension of the traditional radio function. Unlike the case with Tufan (2020), Overbeek (2016) sees podcasts as a disruptive technology from the traditional radio industry in terms of commercialism and listener reach. That is why he said that perhaps the true sign of podcast shifting into a formidable competitor to $\mathrm{AM} / \mathrm{FM}$ radio would be mentioned in Nielsen's next quarterly report.

Regardless of the paradox conceptually put forward by some of these experts, whether podcasts are an extension of traditional radio or whether podcasts shift and replace the role of old radio, what is clear is that the presence of podcasts is a message of a change in civilization in humans. People who used to be quite satisfied and felt that they had benefited from traditional radio at the end of the $19^{\text {th }}$ century now conventional radio seems not enough to meet their information needs. People with high mobility and activity seem to demand the presence of media that is easy to reach, can be accessed at any time, at a low cost, and of course, can provide all the information needed. Thus, the criticism from Steiner and Xu (2018), which suggests looking at the role of the media in shaping audience activeness, needs to be reexamined because it is not only the media that dominates the behavior of the audience but the social conditions or civilization of society, which are also a factor behind the use of media cutting-edge like podcasts. A podcast is present as an alternative media for da'wah. It can be said to be a message that the current context in society emphasizes the activities of auditory needs for those who have high mobility or who want to follow $d a$ 'wah messages without excess quota and battery. Because it must be acknowledged that humans create the communication media, they will create something they need. Moreover, what needs to be emphasized here is that nothing is dominant. There is only a cycle that influences each other. We cannot ignore the role of humans to encourage the presence of new media, such as podcasts, and we also cannot deny that the presence of these new media and all the facilities provided triggers user activity in choosing the media they want.

\section{CONCLUSION AND SUGGESTIONS FOR FURTHER RESEARCH}

From some of the descriptions above, the conclusion that can be drawn is the use of 
podcasts as a medium of $d a^{\prime}$ wah in terms of communicators who upload $d a$ 'wah content of Gus Baha. Those who act as listeners alike agree that in certain cases, this media is effective enough to become an alternative for auditory types, save data and battery, and those with high mobility. So that when viewed from the uses and gratification theory, listeners are quite active in choosing media to fulfill these desires. Furthermore, from the theory of media ecology, the presence of podcasts is a message that now people are interested in audio media with more modern features after previously this media was not very popular and instead switched to audiovisual media, such as television, Facebook, YouTube, Instagram, and others. Meanwhile, in terms of communicators, it can be said that the presence of podcasts is an adaptive and dominant effort economically and politically to maintain the existence of the Nahdlatul Ulama organization in Indonesia.

From these conclusions, suggestions for further research can be formulated, which simultaneously shows the limitations of this study. When this research is still focused on one podcast media, in the future, there needs to be a mapping of the comparison of the facilities or roles offered by each mass media between conventional and new media as well as among the new media itself. It is important to do to obtain a comprehensive picture in developing a more effective $d a$ 'wah strategy. In addition, when this research is based on a qualitative approach by conducting interviews with several informants about their motives for using podcasts, quantitative-based research is also needed to reach more respondents and find out what media they use and the strengths and weaknesses of each media according to respondents (in the context as a medium for da'wah).

\section{ACKNOWLEDGMENT}

The author would like to thank all informants who have been willing to provide data to help smooth this research.

\section{REFERENCE}

Abdullah, M. Q. (2019). Pengantar ilmu dakwah [Introduction to da'wah]. Qiara Media.

Abdulrahman, T., Basalama, N., \& Widodo, M. R. (2018). The impact of podcasts on EFL student's listening comprehension. International Journal of Language Education, 2(2), 23-33. https://doi. org/10.26858/ijole.v2i2.5878

Alfian, Lio, A., \& Marafat, L. O. S. (2019). The use of audio podcast for teaching listening comprehension. Journal of Language Education and Educational Technology, 4(1), 1-11.

Aziz, A. (2017). Ilmu da'wah [Da'wah science]. Kencana.

Briandana, R., Doktoralina, C. M., \& Hassan, S. A. (2020). Da'wah communication and social media: The interpretation of millennials in Southeast Asia. International Journal of Economics and Business Administration, 8(1), 216-226. http://dx.doi.org/10.35808/ijeba/543

Dianithi, A. S. (2017). The use of podcast to improve the speaking competency of the tenth grade students of SMA Negeri 1 Amlapura in academic year 2015/2016. Journal of Education Action Research, 1(1), 30-39. https://ejournal.undiksha. ac.id/index.php/JEAR/article/view/10121/6444 
Euchner, J. (2016). The medium is the message. Research-Technology Management, 59(5), 9-11. https://doi.org/10.1080/08956308.2016.1209068

Harahap, S. D. (2020). Podcast impacts on students listening skill: A case study based on student's perceptions. Jurnal Inovasi Penelitian, 1(4), 891-900. https://doi.org/10.47492/jip.v1i4.166

Hidayati, F. R., \& Irwansyah. (2021). Avoiding Zoom fatigue: The uses and gratifications on social media. Channel Jurnal Komunikasi, 9(1), 95-104. http://dx.doi.org/10.12928/channel. v9i1.19510

Hildebrand, J. M. (2021). What is the message of the robot medium? Considering media ecology and mobilities in critical robotics research. Journal of Knowledge, Culture and Communication. https:// doi.org/10.1007/s00146-021-01204-1

Kaddas, B., \& Ishak, I. (2018). Approached da'wah by radio. International Journal of Multidisciplinary Research and Development, 5(8), 47-50. http:// www.allsubjectjournal.com/archives/2018/vol5/ issue $8 / 5-8-22$

Laskowska, M., \& Marcynski, K. (2019). Media ecology - (Un)necessary research perspective in communication and media studies. Mediatization Studies, 3(53), 54-68. https://doi.org/10.17951/ ms.2019.3.53-68

Littlejohn, S. W., Foss, K., \& Oetzel, J. G. (2017). Theories of human communication. Waveland Press.

Mehrad, J., \&Tajer, P. (2016). Uses and gratification theory in connection with knowledge and information science: A proposed conceptual model. International Journal of Information Science and Management, 14(2), 1-14. https:// ijism.ricest.ac.ir/index.php/ijism/article/ view/787

Mosco, V. (2009). The political economy of communication. SAGE Publications.
Muslikhin, Mulyana, D., Hidayat, D. R., \& Utari, P. (2021). The commodification, spatialization and structuration of social media in the Indonesian cyber media news. Media and Communication, 9(2), 110-118. https://doi.org/10.17645/mac. v9i2.3752

Neubauer, B. E., Witkop, C.T., \& Varpio, L. (2019). How phenomenology can help us learn from the experiences of others. Perspectives on Medical Education, 8, 90-97. https://doi.org/10.1007/ s40037-019-0509-2

Novrizaldi. (2019, October 3). Next year is predicted to be the year of podcast revival. Gatracom. https://www.gatra.com/detail/news/448877/ gaya $\% 20$ hidup/tahun-depan-diprediksi-jaditahun-kebangkitan-podcast

Overbeek, J. (2016). Are podcasts the new radio? Thresholds in the Macro-Environmen. ETopia. https://doi.org/10.25071/1718-4657.36756

Qarni, W., Syahnan, M., Harahap, I., Nasution, S., \& Fithriani, R. (2019). Verbal and nonverbal factors influencing the success of $d a$ 'wah communication by Ustadz Abdul Somad in the Second Annual International Conference on Language and Literature. KnE Social Sciences, 3(19), 804-812. https://doi.org/10.18502/kss. v3i19.4906

Redaksi. (2021, March 26). Sang Ulama kharismatik, ini profil singkat Gus Baha [The charismatic Ulama, this is Gus Baha's brief profile]. Acehnews.id. https:/www.acehnews.id/news/ sang-ulama-kharismatik-ini-profil-singkat-gusbaha/index.html

Rijali, A. (2018). Analisis data kualitatif [Qualitative data analysis]. Jurnal Alhadharah, 17(33), 8195. http://dx.doi.org/10.18592/alhadharah. v17i33.2374

Rusydiyah, E. F., Sa'diyah, H., \& Azizah, M. (2020). The millennial Kiais: Contemporary Indonesian $d a$ 'wah activism through social media. Episteme: Jurnal Pengembangan 
Ilmu Keislaman, 15(1), 75-97. https:/doi. org/10.21274/epis.2020.15.1.75-97

Sansinadi, I. T., Wardhany, D.S. \& Winarko. (2020). Podcast Usage: Expanding English Learning of Undergraduate Student at Universitas Ahmad Dahlan. Journal of English Teaching and Research. 5 (1), 13-24. https://doi.org/10.29407/ jetar.v5i1.14033

Scutter, S., Stupans, I., Sawyer, T., \& King, S. (2010). How do students use podcasts to support leraning? Australian Journal of Educational Technology, 26(2), 180-191. https://doi. org/10.14742/ajet.1089

Siagian, H. F., Mustari, \& Ahmad, F. (2016). The position of $d a^{\prime}$ wah messages and ethics in Malaysian and Indonesian television programs. Malaysian Journal of Communication, 32(2), 749-769. http://ejournal.ukm.my/mjc/article/ view/16503

Sule, M. M., \& Sulaiman, Y. (2021). Enhancing $d a ' w a h$ and spread of knowledge via social media platforms. Jurnal Ilmiah Peuradeun, 9(1), 145-160. https://doi.org/10.26811/peuradeun. v9i1.549

Steiner, E., \& Xu, K. (2018). Binge-watching motivates change: Uses and gratifications of streaming video viewers challenge traditional TV research. Convergence: The International Journal of Research into New Media Technologies, 26(1), 1-20. https://doi. org/10.1177/1354856517750365
Tufan, F. (2020). Podcasting trends of radio stations in Turkey. In A. A. Gul, Y. D. Erturk, \& P. Elmer (Eds.), Digital transformation in media and society (pp. 63-84). Istanbul University Press.

Wasko, J., Murdock, G., \& Sousa, H. (2011). Introduction: The political economy of communications core concerns and issues. In J. Wasko, G. Murdock, \& G. Sousa (Eds.), The handbook of political economy of communications (pp. 1-10). Blackwell Publishing.

Wibowo, A. (2019). Penggunaan media sosial sebagai trend media dakwah pendidikan Islam di era digital [The use of social media as a media trend for Islamic education da'wah in the digital age]. Jurnal Islam Nusantara, 3(2), 339-356. https:// jurnalnu.com/index.php/as/article/view/141

Zaenudin, A. (2019, April 2). Da'wah podcast, dari Kanal Ulil Abshar Abdalla hingga kajian hijrah [Da'wah podcast, from Ulil Abshar Abdalla Channel to hijrah studies]. Tirto.id. https://www. google.com/amp/s/amp.tirto.id/da'wah-podcastdari-kanal-ulil-abshar-abdalla-hingga-kajianhijrah-dkRy

Zellatifany, C. M. (2020). Trends in disseminating audio on demand content through podcast: An opportunity and challenge in Indonesia. Jurnal Pekommas, 5(2), 117-132, https://doi. org/10.30818/jpkm.2020.2050202 
